\title{
Biomaterials
}

Biomaterials 22 (2001) 3179-3189

www.elsevier.com/locate/biomaterials

\section{A study on grafting and characterization of HMDI-modified calcium hydrogenphosphate}

\author{
Guo-Chung Dong ${ }^{\mathrm{a}}$, Jui-Sheng Sun ${ }^{\mathrm{b}}$, Chun-Hsu Yao ${ }^{\mathrm{c}}$, George J. Jiang ${ }^{\mathrm{a}}$, \\ Chin-Wang Huang ${ }^{\text {a }}$, Feng-Huei Lin ${ }^{\text {d,* }}$ \\ ${ }^{a}$ Department of Chemistry, Chung Yuan Christian University, Chungli, Taiwan, ROC \\ ${ }^{\mathrm{b}}$ Department of Orthopedic Surgery, National Taiwan University Hospital, College of Medicine, Taipei, Taiwan, ROC \\ ${ }^{\mathrm{c}}$ Department of Radiological Technology, Chungtai Institute of Health Science and Technology, Taichung, Taiwan, ROC \\ ${ }^{\mathrm{d}}$ Institute of Biomedical Engineering, National Taiwan University, College of Medicine, Taipei, Taiwan, ROC
}

Received 4 July 2000; accepted 12 February 2001

\begin{abstract}
It is known that the organic molecules can provide an effective means to manipulate the surface properties of the biodegradable ceramic. There are two ways to modify the surface of the biodegradable ceramic by organic molecules. The first one is through surface adsorption but organic molecules will easily be washed out in the physiological environment. The second approach is to graft organic molecules through covalent bond to the hydroxyl groups that are available on the surface of the ceramics. Isocyanate group has been reported as a coupling agent for hydroxyapatite and organic molecule. The studies showed that the isocyanate could react with hydroxyl groups of hydroxyapatite and form a covalent bond between isocyanate and hydroxyapatite. In the study, hexamethylene diisocyanate (HMDI) was used as coupling agent and calcium hydrogenphosphate $\left(\mathrm{CaHPO}_{4}\right.$, $\left.\mathrm{CHP}\right)$ was the candidate ceramic. CHP will react with HMDI at the temperature of $20^{\circ} \mathrm{C}, 30^{\circ} \mathrm{C}, 40^{\circ} \mathrm{C}, 50^{\circ} \mathrm{C}, 60^{\circ} \mathrm{C}$, and $70^{\circ} \mathrm{C}$ for $4 \mathrm{~h}$. Dibutyltin dilaurate and hydroquinone were used as catalyst and inhibitor, respectively. The effect of reaction temperature on the grafted yield will be described. The linkage between CHP and HMDI will be characterized by DTA, TGA, FTIR, XRD, and ${ }^{31} \mathrm{P},{ }^{13} \mathrm{C}$ liquid state NMR. From the results, we successfully modified the surface of CHP with coupling agent of HMDI. The grafted yield of HMDI on $\mathrm{CHP}$ was increasing with the reaction temperature. The best temperature for CHP modified by $\mathrm{HMDI}$ is around $50^{\circ} \mathrm{C}$. The linkage between HMDI and the surface of CHP is a urethane linkage as $\mathrm{CHP}-\mathrm{O}-\mathrm{CO}-\mathrm{NH}-\left(\mathrm{CH}_{2}\right)_{6}-\mathrm{N}=\mathrm{C}=\mathrm{O}$. After further treatment, the terminal group of CHP treated with HMDI (MCHP) will be converted into a primary amine group as the formula of $\mathrm{CHP}-\mathrm{O}-\mathrm{CO}-$ $\mathrm{NH}-\left(\mathrm{CH}_{2}\right)_{6}-\mathrm{NH}_{2}$. If reaction temperature is $60^{\circ} \mathrm{C}$, long extension chain will occur with a urea linkage between the isocyanate groups as the formula of $\mathrm{CHP}-\mathrm{O}-\mathrm{CO}-\mathrm{NH}-\left(\mathrm{CH}_{2}\right)_{6}-\left(\mathrm{NH}-\mathrm{CO}-\mathrm{NH}-\left(\mathrm{CH}_{2}\right)_{6}\right)_{n}-\mathrm{NH}_{2}$. At reaction temperature higher than $60^{\circ} \mathrm{C}$, the HMDI will become prepolymerized forms in solution. The prepolymerized forms such as allophanate, biuret, uretidione and urea linkage will turn the solution into gel type mixture, which will lead to low grafted yield of HMDI on CHP. When MCHP prepared at the temperature $20^{\circ} \mathrm{C}$, there is no evidence of long extension but the grafted yield is the lowest only $0.9 \mathrm{wt} \%$ around. C 2001 Elsevier Science Ltd. All rights reserved.
\end{abstract}

Keywords: Hexamethylene diisocyanate (HMDI); Calcium hydrogenphosphate $\left(\mathrm{CaHPO}_{4}, \mathrm{CHP}\right)$; Grafting

\section{Introduction}

The regeneration of physiologically and physically competent bone in deficient skeleton sites can be an elusive goal. To accelerate the healing of bone defects or to enable to heal at all, it is often necessary to fill them

\footnotetext{
*Corresponding author. Tel.: + 886-2-2391-2641; fax: + 886-2-23940049.

E-mail address: double@ha.mc.ntu.edu.tw (F.-H. Lin).
}

with suitable substance. Autogenic graft has been proven as the most suitable graft for bone defect with the properties of osteoinduction and osteoconduction [1]. But the source and amount of the graft are limited, which cannot be used in an extensive bone defect. Allogenic and xenogenic grafts also have some limits in immunology, revascularization, and risk of infection [2]. The degree of care which is required today for choosing, checking, and storing allogenic transplants makes this technique prohibitively expensive, and precludes its general application [1,2]. 
Over the last decades, many efforts have been made to develop new materials for bone substitutes. Among these, calcium phosphates and bioactive glass have been proven to be biocompatibile and bioactive materials that can chemically bond with bone, and have been successfully used clinically for repair of bone defects and augmentation of osseous tissue [3,4]. However, those bioceramics have only the property of osteoconduction without any osteoinduction [5]. The success of the autogenous graft is due to a two-phase phenomenon of repair. The two steps involve direct transfer of viable osteoblasts with the graft and the release of inductive and growth factors from the transplanted bone matrix [6]. The harnessing of these polypeptides and protein factors with a biodegradable, biocompatible delivery system for bone regeneration has been the focus of our efforts.

Growth and differentiation factors lack sufficient structure to prevent soft-tissue prolapsed into bony ablation. Consequently, these factors require a delivery system that would prevent soft-tissue prolapsed and maximize the interaction between the osteoinductive agent and marrow stromal cells. As bone regenerates, the implant should biodegrade. Monolithic block and disk systems have been developed to deliver bone regenerative factors locally and prevent soft-tissue collapse into bone defects. However, monolithic systems occlude the bone marrow cavity, which is the most plentiful source of osteoprogenitor cells. To overcome this drawback, our group is developing a multi-phase system bone implant that consists of a biodegradable ceramic with surface modified by organic molecules, which will play a role as a connector between osteogenic factors and biodegradable ceramics. The organic molecules will provide an effective means to manipulate the surface properties of the biodegradable ceramic. There are two ways to modify the surface of the biodegradable ceramic by organic molecules. The first one is through surface adsorption. It is known that many polymers and proteins can be firmly adsorbed onto the surface of the ceramics. The second approach is to graft organic molecules through covalent bonding to the hydroxyl groups that are available in the surface of the ceramics [7-10].

In 1996, Qing Liu and K de Groot have studied the reactivity of isocyanate with hydroxyapatite. They showed there was covalent bond between isocyanate and hydroxyapatite [11-12]. Under comparable conditions, hexamethylene diisocyanate (HMDI) was more suitable to modify hydroxyapatite surface with polymer [12], such as PEG, PEG/PBT or PMMA etc. [11,13-15]. However, there had been no direct evidence that the surface hydroxyl group was involved in these reactions. In the study, calcium hydrogenphosphate $\left(\mathrm{CaHPO}_{4}\right.$, CHP) would be the candidate ceramic due to its property of biodegradation and higher content of hydroxyl group on the surface of the crystal, which will be used to crosslink with the organic molecules. HMDI was used as coupling agent to modify the surface of CHP. After surface modified, CHP will be grafted with HMDI molecule by a urethane linkage and left an amine group in the tail. The amine tail will be designed to graft with osteogenic factors or Chinese herb medicines to promote osteogenesis in the future. In the study, FTIR, DTA/TGA, ${ }^{13} \mathrm{C}-$ and ${ }^{31} \mathrm{P}-\mathrm{NMR}$ will be used to characterize the modified surface of CHP [16-20].

\section{Materials and methods}

HMDI was purchased from Aldrich and used in the experiments without further purification. $\mathrm{CaHPO}_{4}$, CHP powder was prepared by heating calcium hydrogen-phosphate dihydrate $\left(\mathrm{CaHPO}_{4} \cdot 2 \mathrm{H}_{2} \mathrm{O}\right)$ at $200^{\circ} \mathrm{C}$ for about $8 \mathrm{~h}$, which has been proven as pure CHP both by FTIR and X-ray diffraction (XRD) spectroscopy. Dimethyl formamide (Aldrich, DMF) was purified with distillation and stored over molecular sieves of $4 \AA$. Both hydroquinone and dibutyltin dilaurate used without purification were purchased from Acros.

\subsection{The grafting procedure}

A typical procedure for CHP surface modification is briefly described as follows. $12 \mathrm{~g}$ of dried $\mathrm{CaHPO}_{4}$ powder with an average grain size of about $0.1 \mu \mathrm{m}$, $150 \mathrm{ml}$ of DMF, dibutyltin dilaurate $(0.12 \mathrm{ml})$ and hydroquinone $(200 \mathrm{mg})$ were put into a $250 \mathrm{ml}$ flask. In the system, dibutyltin dilaurate and hydroquinone were used as catalyst and inhibitor, respectively. The flask was then stirred for $1 \mathrm{~h}$ in $\mathrm{N}_{2}$ atmosphere with a flow rate of $100 \mathrm{ml} / \mathrm{min}$ to make sure the reaction in water free condition. $6 \mathrm{ml}$ HMDI was added to the flask subsequently. The reaction was kept at a certain temperature under $\mathrm{N}_{2}$ protection for $4 \mathrm{~h}$ to graft HMDI onto the surface of $\mathrm{CHP}$, which was as so-called surface modified CHP (MCHP). The MCHP powder was filtered and washed with DMF for three times to remove excess HMDI-oligomer. MCHP was then further washed with acetone for three times to remove the residual DMF.

\subsection{FTIR spectroscopy}

Fourier transformation infrared (FTIR) spectra were recorded in the region of $650-4000 \mathrm{~cm}^{-1}$ with a resolution of $2 \mathrm{~cm}^{-1}$ in 100 scans by a diffusive reflection mode. Jasco FT/IR 410 series spectrometer (Tokyo, Japan) equipped with a DLATGS KBr (deuterated light attenuated triglycine sulfate with potassium bromide windows) detectors was used in the study. The highintensity source offers practically better signal to noise and sensitivity when compared to a conventional nichrome light source. The upper spectrum was 
obtained with new light source, and the lower window was obtained with a conventional nichrome light source. $10 \mathrm{mg}$ MCHP powder was mixed with $100 \mathrm{mg} \mathrm{KBr}$ powder, which was used as dilute agent during analysis. The standard analysis program includes all data processing functions used in IR analysis. The program includes peak detection, baseline correction, KK conversion, KM conversion, curve fitting, de-convolution, and may other programs. In addition to the standard data format, spectral data can be saved in JACMP-DX or text formats for use in other analysis programs. All the data can be retrieved and utilized within spectra Manager.

HMDI grafted on the surface of CHP is only a relatively small amount that will lead to a weak absorption on IR. In the study, MCHP powder would be treated by $10 \%$ nitric acid aqueous to remove the ceramic part. Both $10 \%$ nitric acid treated and nontreated MCHP will be used to FTIR analysis later.

\subsection{Thermal analysis (DTA/TGA)}

The thermal gravimetric analysis (TGA) and the differential thermal analysis (DTA) were performed by a system of SDT 2960 (TA Instruments, Inc., 109 Lukens Drive, New Castle, DE 19720). The instrument measures the amount and rate of weight change of a specimen, either as a function of increasing temperature, or isothermally as function of time in air. At the same time, it can be used to determine the temperatures of endothermic and exothermic transitions at temperature up to $1500^{\circ} \mathrm{C}$. In the study, the analysis temperature was from room temperature to $600^{\circ} \mathrm{C}$ at a rate of $20^{\circ} \mathrm{C} / \mathrm{min}$. $20 \mathrm{mg}$ MCHP powder was put into a alumina crucible for analysis and $10 \mathrm{mg} \alpha-\mathrm{Al}_{2} \mathrm{O}_{3}$ powder was put into the reference port as reference material. The amount of HMDI grafted on the surface of CHP was supposed to be equal to the weight loss during the heating and it expressed as weight percentage of the powder's total weight.

\subsection{Nuclear magnetic resonance (NMR)}

The regular ${ }^{13} \mathrm{C}-\mathrm{NMR}$ and ${ }^{31} \mathrm{P}-\mathrm{NMR}$ spectra were collected on a Bruker AVANCE-300 instrument with ${ }^{13} \mathrm{C}$ and ${ }^{31} \mathrm{P}$ frequencies of 75.47 and $121.49 \mathrm{MHz}$, respectively. The MCHP powder would be treated with $1 \mathrm{M} \mathrm{NaOH}$ aq and then filtered by filter paper. The filtered powder would be collected for XRD analysis later and the filtered solution would be used for ${ }^{31} \mathrm{P}$ NMR analysis. As to the sample preparation for ${ }^{13} \mathrm{C}$ NMR analysis, MCHP would be dissolved in $20 \% \mathrm{DCl}$ solution. ${ }^{13} \mathrm{C}$-NMR shifts are in ppm relative to external methanol- $\mathrm{d}_{4}\left(\mathrm{CD}_{3} \mathrm{OD}\right)$ and ${ }^{31} \mathrm{P}$ spectra were relative to $85 \% \mathrm{H}_{3} \mathrm{PO}_{4} \cdot{ }^{31} \mathrm{P}$ non-decoupled NMR model would be used in the study.

\subsection{X-ray diffractometer (XRD)}

The crystalline phases of specimens were determined by Rigaku X-ray powder diffractometer with $\mathrm{CuK}_{\alpha}$ radiation and $\mathrm{Ni}$ filter. The scanning range of the samples was from $10^{\circ}$ to $60^{\circ}$ with a scanning speed of $4^{\circ} \%$ min. Crystalline was identified by computer automatched system with standard data file (JCPDS).

\section{Results}

\subsection{Thermal analysis}

Fig. 1(a) is the DTA analysis of CHP powder. It shows that an endothermic peak appears at the temperature of $455.8^{\circ} \mathrm{C}$, which is due to the phase transformation of CHP to dicalcium pyrophosphate $\left(\mathrm{Ca}_{2} \mathrm{P}_{2} \mathrm{O}_{7}\right)$. Fig. 1(b) is the result of TGA analysis of CHP powder. There is an obvious weight loss at the temperature of $445-482^{\circ} \mathrm{C}$, which is corresponding to two moles CHP phase transformation accompanied with one mole $\mathrm{H}_{2} \mathrm{O}$ loss. Fig. 2(a) is the DTA curve for MHCP powder that is CHP grafted with HMDI. There are one exothermic peak and one endothermic peak at the temperature of $294.6^{\circ} \mathrm{C}$ and $422.2^{\circ} \mathrm{C}$, respectively. The endothermic peak at the temperature of $422.2^{\circ} \mathrm{C}$ is also related with the $\mathrm{CHP}$ phase transformation, which is in agreement with Fig. 1(a). The exothermic peak at $294.6^{\circ} \mathrm{C}$ is due to HMDI burning. The TGA curve for MHCP is shown in Fig. 2(b). It shows two weight loss regions. At the first region, the weight loss is due to HMDI burning. The weight loss at the second region is resulted from $\mathrm{H}_{2} \mathrm{O}$ loss during the phase transformation of $\mathrm{CHP}$, which is in agreement with the result of Fig. 1.

In order to elucidate the effect of temperature on the grafted yield, we grafted HMDI onto the surface of

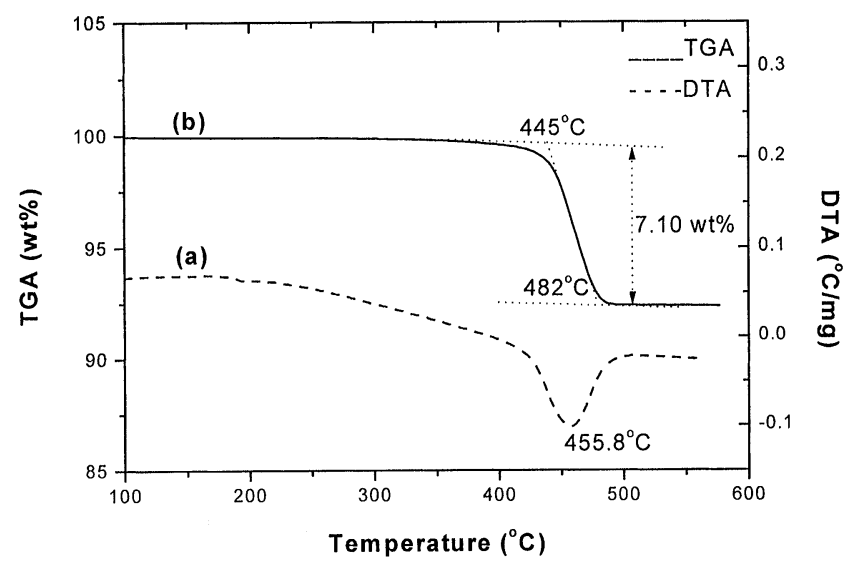

Fig. 1. (a) DTA curve of CHP powder, and (b) TGA curve of CHP powder. 


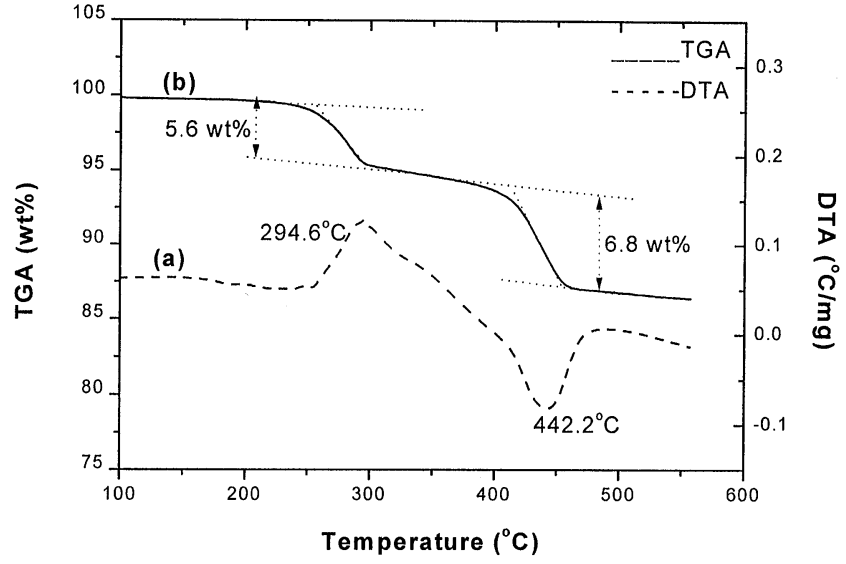

Fig. 2. DTA curve (a) and the TGA curve (b) of MHCP.

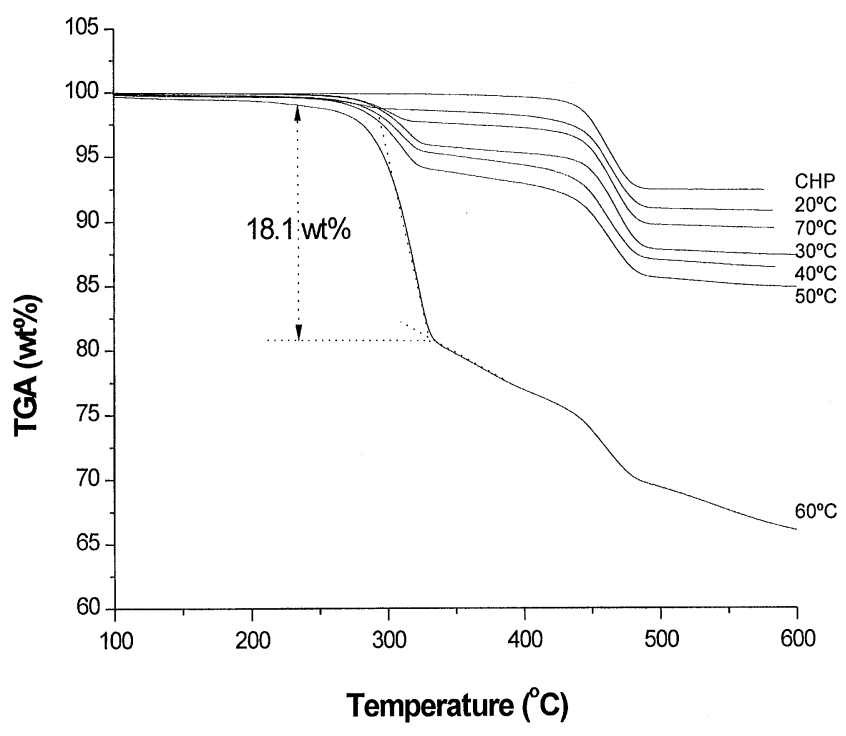

Fig. 3. TGA curves of MCHP prepared at different temperatures.
CHP at the temperature of $20^{\circ} \mathrm{C}, 30^{\circ} \mathrm{C}, 40^{\circ} \mathrm{C}, 50^{\circ} \mathrm{C}$, $60^{\circ} \mathrm{C}$, and $70^{\circ} \mathrm{C}$, individually. Fig. 3 shows the TGA curves of MCHP prepared at different temperatures. All the curves have two weight loss regions that are related to organic evaporation and the phase transformation as described in Figs. 1 and 2. The amount of weight loss at the first region increases with the reaction temperature. When the reaction temperature up to $60^{\circ} \mathrm{C}$, it has a greatest amount of HMDI grafted onto the surface of CHP around $18.1 \mathrm{wt} \%$. However, the amount decreases thereafter. The amount of weight loss at second region shows no significant difference for each curve as shown in Table 1 . Fig. 4 is the DTA curves for MCHP prepared at different temperatures. Each curve shows one exothermic peak and one endothermic peak as Fig. 1(a), where the exothermic one is responsible for HMDI burning and endothermic one is for the phase transformation. As Fig. 4 shown, the intensity of exothermic peak has a positive tendency with the reaction temperature of HMDI grafting. There is a highest exothermic peak when $\mathrm{MHCP}$ prepared at $60^{\circ} \mathrm{C}$, but decrease thereafter.

\subsection{NMR analysis}

Fig. 5 is the ${ }^{31} \mathrm{P}-\mathrm{NMR}$ spectrum of filtered solution after MCHP treated with $1 \mathrm{~m} \mathrm{NaOH}$. The spectrum shows a distinctive resonance peak of ${ }^{31} \mathrm{P}-\mathrm{O}-\mathrm{C}$ at the position of $5.74 \mathrm{ppm}$, which is assigned to the urethane linkage between HMDI and CHP after reacted. There is not any multiplet peaks present in the spectrum.

The regular ${ }^{13} \mathrm{C}-\mathrm{NMR}$ spectrum and ideal structure for pure HMDI is shown in Fig. 6(a). There are eight carbons at main chain on the HMDI ideal structure. We assigned different number on each carbon as $1,2,3, \ldots, 8$. There are only four

Table 1

The amount of weight loss in 1st- and 2nd-stage obtained by using TGA

\begin{tabular}{|c|c|c|c|c|c|c|c|c|}
\hline Sample & $\begin{array}{l}W_{\text {1st-stage }} \\
\text { wt } \%\end{array}$ & $\begin{array}{l}W_{1 \text { st-stage }} \\
\mathrm{mg}\end{array}$ & $\begin{array}{l}W_{2 \text { nd-stage }} \\
\text { wt } \%\end{array}$ & $\begin{array}{l}W_{\text {2nd-stage }} \\
\mathrm{mg}\end{array}$ & $\begin{array}{l}N_{\mathrm{CHP}}{ }^{\mathrm{a}} \\
\mu \mathrm{mol}\end{array}$ & $\begin{array}{l}N_{\mathrm{MCHP}}{ }^{\mathrm{a}} \\
\mu \mathrm{mol}\end{array}$ & $\begin{array}{l}N_{\text {reacted-CHP }}{ }^{\mathrm{b}} \\
\mu \mathrm{mol}\end{array}$ & $\begin{array}{l}M_{\text {average }}{ }^{\mathrm{c}} \\
\mathrm{g} / \mathrm{mol}\end{array}$ \\
\hline CHP & & & 7.10 & 0.71 & 78.88 & & & \\
\hline \multicolumn{9}{|l|}{ МCHP } \\
\hline $20^{\circ} \mathrm{C}$ & 0.9 & 0.09 & 7.05 & 0.70 & & 78.33 & 0.55 & 164 \\
\hline $30^{\circ} \mathrm{C}$ & 4.0 & 0.40 & 6.90 & 0.69 & & 76.66 & 2.22 & 180 \\
\hline $40^{\circ} \mathrm{C}$ & 4.3 & 0.43 & 6.87 & 0.69 & & 76.33 & 2.55 & 169 \\
\hline $50^{\circ} \mathrm{C}$ & 5.6 & 0.56 & 6.80 & 0.68 & & 75.56 & 3.32 & 169 \\
\hline $60^{\circ} \mathrm{C}$ & 18.1 & 1.81 & 6.44 & 0.64 & & 71.56 & 7.32 & 247 \\
\hline $70^{\circ} \mathrm{C}$ & 2.0 & 0.20 & 7.00 & 0.70 & & 77.78 & 1.10 & 182 \\
\hline
\end{tabular}

${ }^{\text {a }} N_{\mathrm{CHP}}, N_{\mathrm{MCHP}}=2 \times\left(W_{2 \text { nd-stage }} / 18\right)$.

${ }^{\mathrm{b}} N_{\text {reacted-CHP }}=N_{\mathrm{CHP}}-N_{\mathrm{MCHP}}$.

${ }^{\mathrm{c}} M_{\text {average }}=W_{1 \text { st-stage }} / N_{\text {reacted-CHP. }}$. 
resonance peaks because HMDI is a symmetrical structure. $\mathrm{C} 1$ and $\mathrm{C} 8$, for instance, have the same environment in the structure so that the peak should appear at the same position of $121.61 \mathrm{ppm}$. The peak at $121.61 \mathrm{ppm}$ is isocyanate group $\mathrm{O}={ }^{13} \mathrm{C}=\mathrm{N}$, which will shift to $158.38 \mathrm{ppm}$ after HMDI react with CHP at the temperature of $50^{\circ} \mathrm{C}$, as shown in Fig. 6(b). In Fig. 6(a), the peak of $\mathrm{C} 2$ and $\mathrm{C} 7$ is at the position of $42.29 \mathrm{ppm}$. This peak will shift to $40.12 \mathrm{ppm}$ if the tailed isocyanate group become an amine group (Fig. 6(b)). The C2 peak at the Fig. 6(b) will split and shift to $40.88 \mathrm{ppm}$.

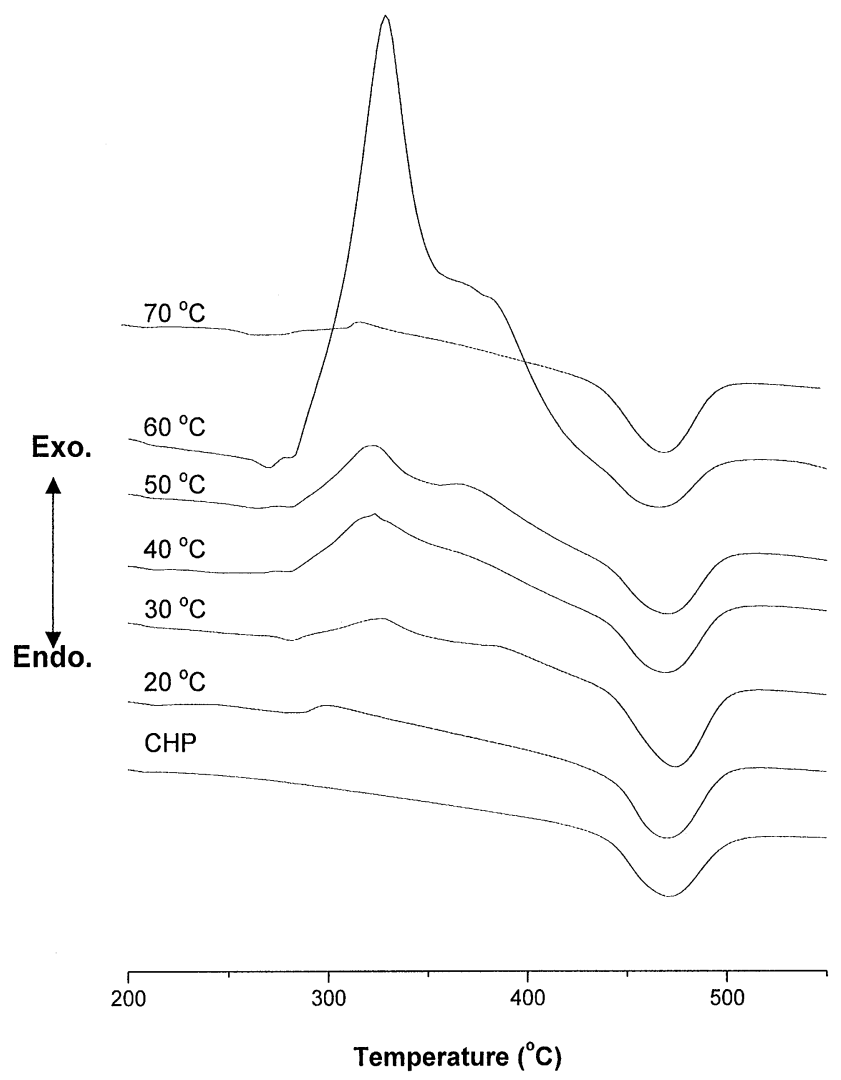

Fig. 4. DTA curves for MCHP prepared at different temperatures.
Fig. 6(c) shows regular ${ }^{13} \mathrm{C}-\mathrm{NMR}$ spectrum and model structure for $\mathrm{MCHP}$ prepared at $60^{\circ} \mathrm{C}$. The spectrum also have a peak around the position of $159.03 \mathrm{ppm}$ but shows a side resonance peak at the position of $159.95 \mathrm{ppm}$. The side peak is due to HMDI molecule prepolymerization and graft to MCHP, which causes grafting main chain to long extension. The side peak also occurs at the other peaks because of long chain extension.

\subsection{FTIR analysis}

Fig. 7(a) is the FTIR spectrum of CHP, which shows a typically CHP spectrum. Fig. 7(b) shows the spectrum of MCHP without $10 \%$ nitric acid treatment. There are several extra peaks appeared on the MCHP pattern but the intensity of the extra peaks is very weak. In this study, ceramic part of MCHP will be removed with $10 \%$ nitric acid treatment and then analyzed by FTIR. We did not observe any absorption band of isocyanate group $(\mathrm{O}=\mathrm{C}=\mathrm{N}-\mathrm{R})$ on the spectrum of MCHP, as arrowhead on Fig. 7(b). It can be deduced that all the isocyanate groups are involved into the grafting reaction.

Fig. 7(c) are the FTIR pattern of MCHP with $10 \%$ nitric acid treatment. The presence of urethane peaks are at $3138,1716,1580,1479,1255$, and $1077 \mathrm{~cm}^{-1}$. The peak at $3138 \mathrm{~cm}^{-1}$ is assigned to $\mathrm{N}-\mathrm{H}$ stretching vibration. $1580 \mathrm{~cm}^{-1}$ was the combination of $\mathrm{N}-\mathrm{H}$ deformation and $\mathrm{C}-\mathrm{N}$ stretching vibration and at $1255 \mathrm{~cm}^{-1}$ was the absorption band of combination $\mathrm{C}_{-}$ $\mathrm{N}$ and $\mathrm{C}-\mathrm{O}$ stretching vibration. A weak peak at $1716 \mathrm{~cm}^{-1}$ was the urethane carbonyl group. It is worthy note that a very clear peak can be observed at the position around $1100-1050 \mathrm{~cm}^{-1}$, which is resulted from asymmetric stretching vibration of $\mathrm{P}-\mathrm{O}-\mathrm{C}$ group.

In addition, the absorption bands at 1520, 1479 and $1439 \mathrm{~cm}^{-1}$ are due to carbonyl coupled with $\mathrm{N}-\mathrm{H}$ and $\mathrm{N}-\mathrm{C}-\mathrm{N}$ stretching vibration, respectively. It reflects that secondary urea linkage is existed when MCHP prepared

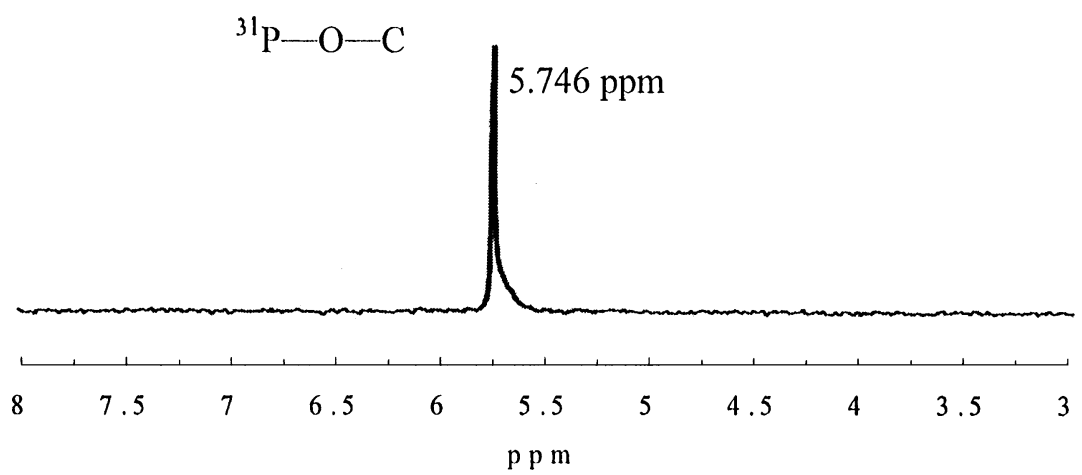

Fig. 5. ${ }^{31} \mathrm{P}-\mathrm{NMR}$ non-decoupled spectrum of the filtered solution after $\mathrm{MCHP}$ treated with $1 \mathrm{M} \mathrm{NaOH}_{\mathrm{aq}}$. 
<smiles>NNPNPNCNC(=O)NCCCCCNC(=O)OP(=O)(O)O[Ge]</smiles>

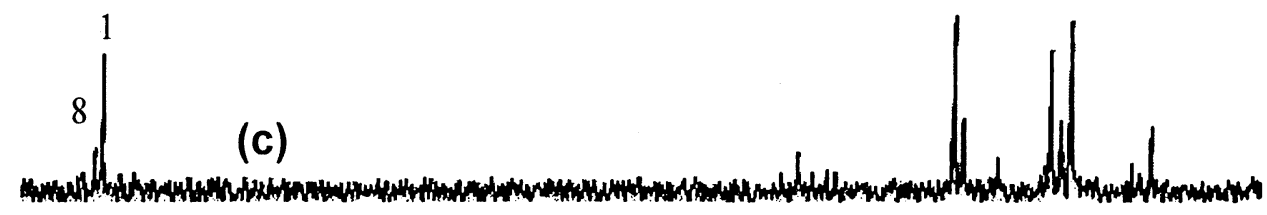<smiles>NP[IH]SC[IH]NC(=O)OP(=O)([O-])[O-]</smiles>
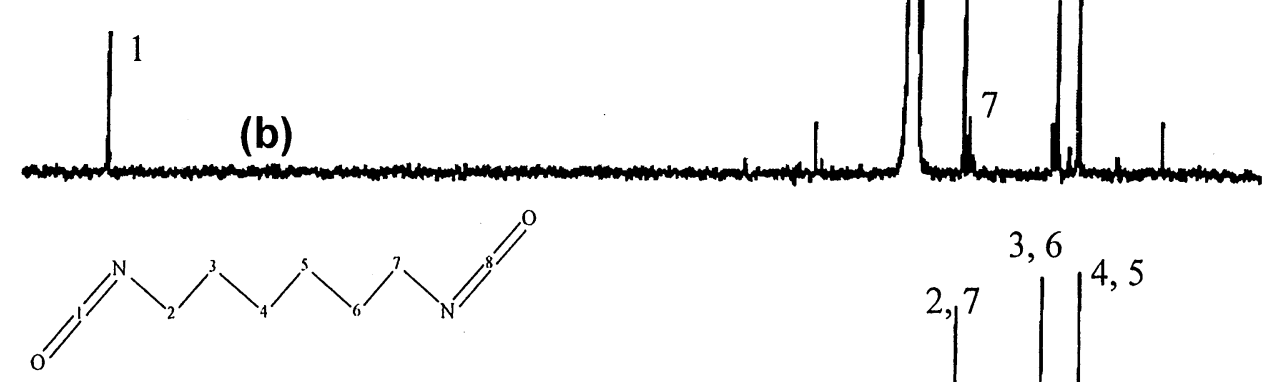

3,6

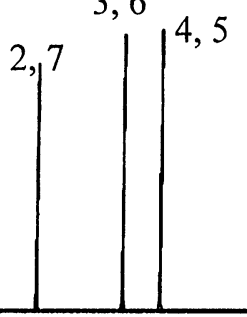



Fig. 6. ${ }^{13} \mathrm{C}$-NMR spectra of (a) pure HMDI, (b) the filtered solution of MCHP (prepared at $50^{\circ} \mathrm{C}$ ) after treated with $1 \mathrm{M} \mathrm{NaOH}(\mathrm{c})$ the filtered solution of MCHPM (prepared at $60^{\circ} \mathrm{C}$ ) after treated with $1 \mathrm{M} \mathrm{NaOH}$.

above $60^{\circ} \mathrm{C}$. Some peaks at 3327,1615 and $773 \mathrm{~cm}^{-1}$ were assigned to deformation and stretching vibration of $\mathrm{NH}_{2}$. The absorption bands at 2930, 2857, 1461 and 773 are asymmetrical vibration, symmetrical vibration, skeleton vibration, and deformation vibration of $-\mathrm{CH}_{2}$, respectively. The other one distinct absorption band at $1402 \mathrm{~cm}^{-1}$ is responsible for $-\mathrm{CH}_{2}$ deformation band with an adjacent phosphorous group.

Fig. 8 summaries the FTIR spectra of MCHP prepared at the different temperatures. The intensity of urethane absorption bands at 1716,1580, and $1255 \mathrm{~cm}^{-1}$ increase with the reaction temperature. The intensity of those peaks then goes down after temperature over $60^{\circ} \mathrm{C}$. The intensity of the absorption bands at 1520 and $1479 \mathrm{~cm}^{-1}$ assigned to urea group also increase with the reaction temperature. When the reaction temperature above $70^{\circ} \mathrm{C}$, the urea peaks cannot be observed because HMDI becomes pre-polymerized gel forms.

\section{Discussion}

The isocyanate group employed surface modification has high reactivity. They often occur in prepolymerized forms or as biuret or isocyanurate adducts. Typically, there are three side reactions for isocyanate. The first is the branching due to the additional reaction. The isocyanate group reacts with active hydrogen from a urethane linkage or a urea linkage to give allophanate linkages or biuret linkages. The second is caused by water contaminating the polymerization system. The isocyanate group can react with the water to give an amine and $\mathrm{CO}_{2}$. This amine reacts immediately with another isocyanate group to give a urea compound. The urea compound can be formed with the chain extending reaction. The third is originated from the isomerization of the isocyanate group. Two isocyanate groups can dimerize to form the uretidion compound. Three 


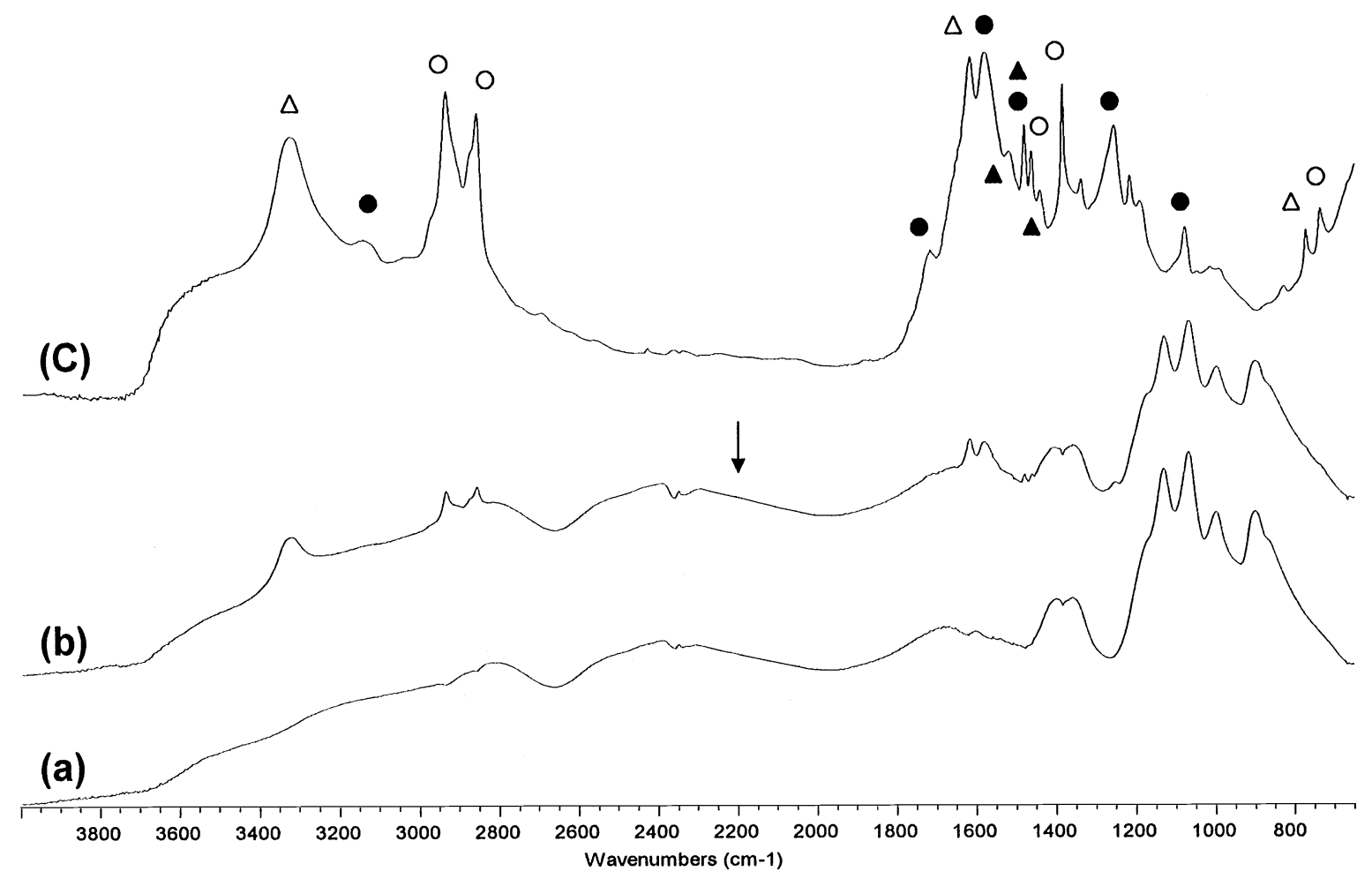

Fig. 7. FTIR spectra of (a) CHP powder, (b) MCHP without nitric acid treatment, and (c) MCHP with nitric acid treatment. Urethane (ム); urea (O); amine $(\triangle) ;-\mathrm{CH}_{2}(\mathrm{O})$.

isocyanate groups can trimerize to give a triazinetrion derivative, which is very stable and incorporated into the polymer chain as a kind of branching point. Because of technological developments, NMR becomes the most useful method for the chemical characterization of these compounds [21-24].

There is only one endothermic peak at the temperature of $455.8^{\circ} \mathrm{C}$ and one weight loss at the same temperature (Fig. 1). It is due to CHP decomposition with one water molecule weight loss and the phase transformation [25]. The CHP decomposition is as follows:

$2 \mathrm{CaHPO}_{4} \rightarrow \mathrm{Ca}_{2} \mathrm{P}_{2} \mathrm{O}_{7}+\mathrm{H}_{2} \mathrm{O}$ (at $400-500^{\circ} \mathrm{C}$ ).

After CHP treated with HMDI, there are two peaks on the DTA pattern and two-stage weight loss on the TGA pattern as shown in Fig. 2. The endothermic peak and the second weight loss at the temperature of $422.2^{\circ} \mathrm{C}$ is due to CHP decomposition. The exothermic peak and the first weight loss at the temperature of $294.6^{\circ} \mathrm{C}$ is due to HMDI burning, which is grafted onto the surface of CHP. With the reaction temperature increased, the first weight loss was increasing (Fig. 3). When the reaction temperature up to $60^{\circ} \mathrm{C}$, the weight loss at $294.6^{\circ} \mathrm{C}$ is about $18.1 \mathrm{wt} \%$ that is much higher than that of any other reaction temperatures.
We can suppose that HMDI grafted on the surface of $\mathrm{CHP}$ is as formulae of [CHP-O-CO-NH- $\left(\mathrm{CH}_{2}\right)_{6}-$ $\mathrm{N}=\mathrm{C}=\mathrm{O}$ ] or as so-called MCHP (Fig. 9(a)). $\mathrm{P}-\mathrm{O}-\mathrm{CO}-$ $\mathrm{NH}-\mathrm{R}$ will be called the urethane linkage later. The urethane linkage can be proven from the spectra of ${ }^{31}$ P-NMR (Fig. 5), ${ }^{13}$ C-NMR (Fig. 6), and FTIR (Figs. 7 and 8), respectively. If the reaction temperature lower than $60^{\circ} \mathrm{C}$, chain extension will not occur in the system.

When HMDI grafted on the surface of CHP at the reaction temperature of $60^{\circ} \mathrm{C}, \mathrm{MCHP}$ will have a long extension chain, which can be formulated as [CHP-O$\left.\mathrm{CO}-\mathrm{NH}-\left(\mathrm{CH}_{2}\right)_{6}-\left(\mathrm{NH}-\mathrm{CO}-\mathrm{NH}-\left(\mathrm{CH}_{2}\right)_{6}\right)_{n}-\mathrm{N}=\mathrm{C}=\mathrm{O}\right]$. The HMDI grafted on the CHP will link other HMDI together with urea linkage of $\mathrm{R}-\mathrm{NH}-\mathrm{CO}-\mathrm{NH}-\mathrm{R}^{\prime}$. We can observe the resonance peaks and absorption bands of urea linkage on the patterns of ${ }^{13} \mathrm{C}$-NMR (Fig. 6) and FTIR (Figs. 7 and 8), respectively. We can abbreviate the [CHP-O-CO-NH- $\left(\mathrm{CH}_{2}\right)_{6}-$ $\left.\left(\mathrm{NH}-\mathrm{CO}-\mathrm{NH}-\left(\mathrm{CH}_{2}\right)_{6}\right)_{n}-\mathrm{N}=\mathrm{C}=\mathrm{O}\right]$ as MCHPM. The long extension will lead to more organic derivatives on the tail of HMDI (Fig. 9(b)). The long extension chain also causes the weight loss at $294.6^{\circ} \mathrm{C}$ of MCHPM much higher than that of any other reaction temperatures.

Once the reaction temperature up to $70^{\circ} \mathrm{C}$, HMDI will become various prepolymerized forms with a gel type 




Fig. 8. The FTIR spectra of (a) CHP powder, (b) MCHP prepared at $20^{\circ} \mathrm{C}$, (c) MCHP prepared at $30^{\circ} \mathrm{C}$, (d) $\mathrm{MCHP}$ prepared at $40^{\circ} \mathrm{C}$, (e) $\mathrm{MCHP}$ prepared at $50^{\circ} \mathrm{C}$, (f) MCHP prepared at $60^{\circ} \mathrm{C}$, and (g) MCHP prepared at $70^{\circ} \mathrm{C}$. Urethane $(\mathbf{\Delta})$; urea (৩).

(a)

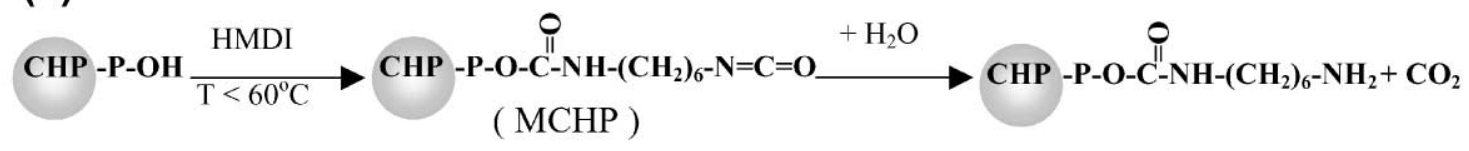

(b)

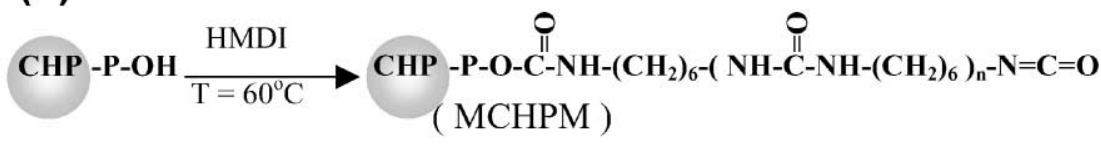

(c) CHP-P-OH $\frac{\mathrm{HMDI}}{\mathrm{T}>60^{\circ} \mathrm{C}} \longrightarrow \mathrm{CHP}-\mathrm{P}-\mathrm{OH}+$ various prepolymerized forms

Fig. 9. The brief scheme of HMDI grafted on the surface CHP at different temperatures. (a) MCHP prepared lower than $60^{\circ} \mathrm{C}$, (b) $\mathrm{MCHP}$ prepared at $60^{\circ} \mathrm{C}(\mathrm{MCHPM})$, and (c) MCHP prepared higher than $60^{\circ} \mathrm{C}$. 
mixture so that only a small amount of HMDI grafted on the surface of CHP (Fig. 9(c)). The result reflects the weight loss at $294.6^{\circ} \mathrm{C}$ of MCHP prepared at $70^{\circ} \mathrm{C}$ turns down very much (Fig. 3). When MCHP prepared temperature higher than $70^{\circ} \mathrm{C}\left(80^{\circ} \mathrm{C}\right.$ for instance $)$, there is not any HMDI grafted on the surface of CHP. The DTA/TGA pattern of MCHP prepared at $80^{\circ} \mathrm{C}$ is similar to that of CHP, which shows no exothermic peak and first weight loss any more.

In addition, one molecular HMDI should react with one hydroxyl group, which located on the surface of CHP. $W_{2 \text { nd-stage }}$ in Table 1 is the secondary weight loss of CHP or MCHP. If $W_{2 \text { nd-stage }}$ divided by molecular weight of $\mathrm{H}_{2} \mathrm{O}(\mathrm{MW}=18)$, it can be in terms of the molecular number of $\mathrm{CaHPO}_{4}$ in $\mathrm{CHP}$ or $\mathrm{MCHP}$ as described $N_{\mathrm{CHP}}$ or $N_{\mathrm{MCHP}}$ in Table 1, respectively. $N_{\mathrm{CHP}}$ is the molecular number of $\mathrm{CaHPO}_{4}$ in $\mathrm{CHP}$, while $N_{\mathrm{MCHP}}$ is the molecular number of $\mathrm{CaHPO}_{4}$ in MCHP. We can calculate the molecular number of CHP reacted with HMDI $\left(N_{\text {reacted-CHP }}\right)$ in MCHP as following equation:

$N_{\text {reacted-CHP }}=\left(N_{\mathrm{CHP}}-N_{\mathrm{MCHP}}\right)$.

We can obtain the average molecular weight of HMDI derivatives grafted on the surface of CHP by Eq. (3) as follows:

$M_{\text {average }}=W_{\text {1st-stage }} / N_{\text {reacted-CHP. }}$.

$M_{\text {average }}$ can be regarded as average molecular weight of the organic part in MCHP, as underlined part of $\mathrm{CHP}-\mathrm{O}-\mathrm{CO}-\mathrm{NH}-\left(\mathrm{CH}_{2}\right)_{6}-\mathrm{N}=\mathrm{C}=\mathrm{O}$. The theoretical molecular weight of HMDI is $168 \mathrm{~g} / \mathrm{mole}$. The $M_{\text {average }}$ of MCHP prepared in $20^{\circ} \mathrm{C}, 30^{\circ} \mathrm{C}, 40^{\circ} \mathrm{C}$, and $50^{\circ} \mathrm{C}$ is $164,180,169$, and $169 \mathrm{~g} /$ mole, respectively. The $M_{\text {average }}$ of MCHP prepared in $30^{\circ} \mathrm{C}, 40^{\circ} \mathrm{C}$, and $50^{\circ} \mathrm{C}$ is very close to the theoretical molecular weight of HMDI. It reflects that there is no extension chain or HMDI prepolymerization to be happened in MCHP prepared at those temperatures. When the reaction temperature up to $60^{\circ} \mathrm{C}$ (MCHPM), the $M_{\text {average }}$ is $247 \mathrm{~g} /$ mole that is much higher than theoretical molecular weight of HMDI. The $M_{\text {average }}$ of MCHPM is the average molecular weight of organic part of MCHPM as underlined part of $\mathrm{CHP}-\mathrm{O}-\mathrm{CO}-\mathrm{NH}-\left(\mathrm{CH}_{2}\right)_{6}-(\mathrm{NH}-$ $\left.\mathrm{CO}-\mathrm{NH}-\left(\mathrm{CH}_{2}\right)_{6}\right)_{n}-\mathrm{N}=\mathrm{C}=\mathrm{O}$. We can expect that extension chain should be happened once MCHP prepared at $60^{\circ} \mathrm{C}$. If reaction temperature is $70^{\circ} \mathrm{C}$, HMDI occurs prepolymerization that leads to only very small amount of HMDI grafted on the surface of CHP ( $W_{\text {1st-stage }}$ in Table 1). The $M_{\text {average }}$ also goes down due to HMDI prepolymeration. When the preparation temperature over $80^{\circ} \mathrm{C}$, there is not any HMDI grafted on CHP because of prepolymerization taking place seriously.

The cross-linking between CHP and HMDI only happens in very surface of MCHP. Before analysis, ceramic part of MCHP should be removed and organic

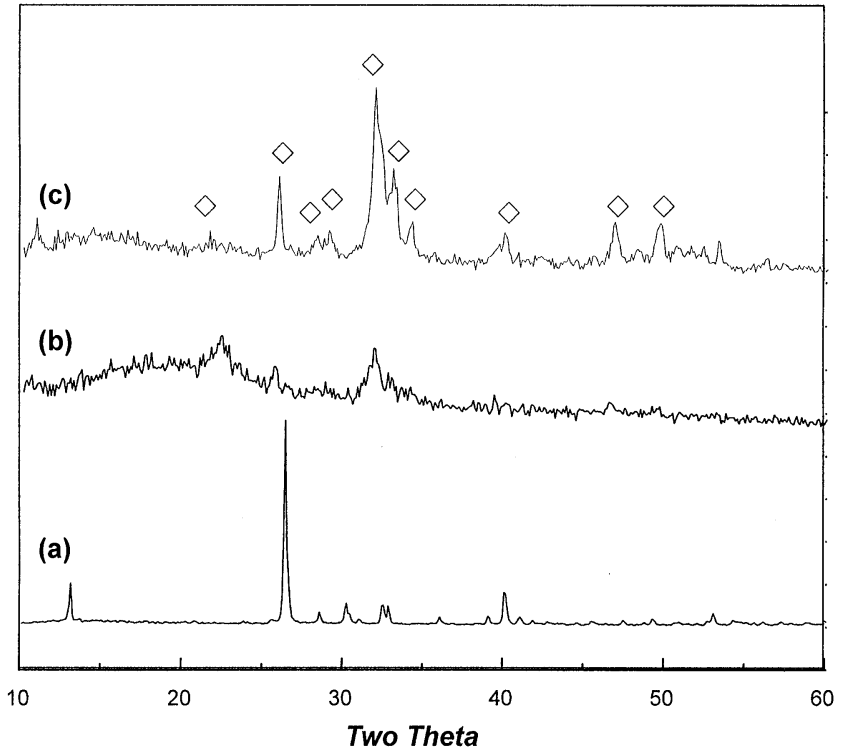

Fig. 10. The XRD patterns of (a) CHP powder, (b) the precipitate of MCHP treated with $1 \mathrm{M} \mathrm{NaOH}$ aq, and (c) the precipitate heated at $1200^{\circ} \mathrm{C}$. Hydroxyapatite $(\diamond)$.

part of MCHP as underlined part of $\mathrm{CHP}-\mathrm{O}-\mathrm{CO}-\mathrm{NH}-$ $\left(\mathrm{CH}_{2}\right)_{6}-\mathrm{N}=\mathrm{C}=\mathrm{O}$ should be left. In order to characterize HMDI derivatives, MCHP were hydrolyzed with a $1 \mathrm{M}$ $\mathrm{NaOH}$ solution. The precipitate of MCHP treated with $1 \mathrm{~m} \mathrm{NaOH}$ solution was identified as an amorphous hydroxylapatite (Hap), which can be identified by XRD (Fig. 10). We can figure that the surface of CHP treated with HMDI can be regarded as CHP-R, where $\mathrm{R}$ is - $\mathrm{O}-$ $\mathrm{CO}-\mathrm{NH}-\left(\mathrm{CH}_{2}\right)_{6}-\mathrm{N}=\mathrm{C}=\mathrm{O}$. CHP at high $\mathrm{pH}$ may be followed by its transformation to Hap via the formation of octacalcium phosphate, which may serve as a template for Hap growth. Therefore, the CHP-R and CHP may co-precipitate as a poorly crystalline Hap in alkaline solution. The $\mathrm{R}-\mathrm{PO}_{4}^{-2}$ may stay in the filtered solution and used for ${ }^{31} \mathrm{P}$ non-decoupled NMR analysis. We give a formula for these results as Eq. (4).

$$
\mathrm{CHP}_{-\mathrm{R}}(\mathrm{s})+\mathrm{CHP}_{(\mathrm{s})} \rightarrow \mathrm{Hap}_{(\mathrm{s})}+\mathrm{RPO}_{4}^{-2}(\mathrm{aq})
$$

(at alkaline solution).

In Fig. 5 , the ${ }^{31} \mathrm{P}$ non-decoupled NMR spectra of the filtered solution showed only a sharp singlet peak at $5.7 \mathrm{ppm}$ and without orthophosphate ions at $4.31 \mathrm{ppm}$ [16]. From the result, we could make sure that the HMDI derivatives (on the surface of MCHP) could be taken out from MCHP by $1 \mathrm{~m} \mathrm{NaOH}$ solution. The presence of single peak can be regards as the formation of organic phosphate [16]. It is worthy note that no multiple peaks can be observed near the resonance of organic phosphate. It reflects that $\mathrm{P}-\mathrm{O}-\mathrm{C}$ bond is formed between HMDI and CHP through the reaction of isocyanates and hydroxyl. There are not any hydrogen bonded to the $\alpha$-carbon because ${ }^{31} \mathrm{P}-\mathrm{O}-\mathrm{C}^{1} \mathrm{H}$ couple is not found in the ${ }^{31} \mathrm{P}$ resonance. 
Generally speaking, the reaction of isocyanate group with hydroxyl groups can form a urethane linkage, which is characterized by a secondary amide absorption bands in FTIR (Fig. 7(c)). The carbonyl absorption band at $1695-1615 \mathrm{~cm}^{-1}$ is one of secondary amide absorption bands. If $-\mathrm{P}-\mathrm{O}-\mathrm{CO}-\mathrm{NH}$ existed, the carbonyl absorption band would be shifting to a higher wave number of $1716 \mathrm{~cm}^{-1}$. The presence of the functional group provides the evidence of $\mathrm{P}-\mathrm{O}-\mathrm{CO}-\mathrm{NH}$ bond formed between HMDI and CHP. The other one absorption band appeared at $1080 \mathrm{~cm}^{-1}$ in Fig. 7(c) is one of evidence of $\mathrm{P}-\mathrm{O}-\mathrm{C}$ formation, which is in agreement with the result of ${ }^{31} \mathrm{P}$ non-decoupled NMR.

After CHP reacted with HMDI, the product will be put into de-ionized water to convert the terminal group of $\mathrm{MCHP}$ (as underlined of $\mathrm{CHP}-\mathrm{O}-\mathrm{CO}-\mathrm{NH}-\left(\mathrm{CH}_{2}\right)_{6}-$ $\mathrm{N}=\mathrm{C}=\mathrm{O})$ into primary amine group $\left(-\mathrm{NH}_{2}\right)$. The three amine absorption bands were clearly identified at 3327 , 1615 and $773 \mathrm{~cm}^{-1}$. Fig. 7 shows no isocyanate absorption band at $2200 \mathrm{~cm}^{-1}$. We can tell that all the isocyanate groups do not exist in the MCHP any more. It indicates that the final product of $\mathrm{CHP}$ reacted with HMDI should be CHP-O-CO-NH- $\left(\mathrm{CH}_{2}\right)_{6}-\mathrm{NH}_{2}$, which is the formation of phosphate urethane and has a terminal amine group.

In Fig. 8(f), two absorption bands corresponding to urea linkage ( $\left.\mathrm{R}-\mathrm{NH}-\mathrm{CO}-\mathrm{NH}-\mathrm{R}^{\prime}\right)$ can be observed at 1520 and $1439 \mathrm{~cm}^{-1}$, which can not be traced at the spectra of MCHP prepared in the temperature lower than $60^{\circ} \mathrm{C}$. As discussed in the previous sections, the long extension will progressively formed when MCHP prepared at the temperature of $60^{\circ} \mathrm{C}$. Furthermore, Fig. 6(c) shows regular ${ }^{13} \mathrm{C}-\mathrm{NMR}$ spectrum and model structure for MCHP prepared at $60^{\circ} \mathrm{C}$. The spectrum also has a peak around the position of $159.03 \mathrm{ppm}$ but shows a side resonance peak at the position of $159.95 \mathrm{ppm}$. The side peak is due to HMDI molecule prepolymerization and graft to MCHP, which causes grafting main chain to long extension at $60^{\circ} \mathrm{C}$.

There are several types of linkage to be formed during isocyanate reaction, such as urea, allophanate, biuret and uretidion. For determined the detail structure of products, the products would be hydrolysis by $20 \% \mathrm{DCl}$ and analyzed by ${ }^{13} \mathrm{C}-\mathrm{NMR}$ in liquid state. In Fig. 6, a small resonance appeared at $159.9 \mathrm{ppm}$. The chemical shift of the resonance peak was too high to consider it as allophanate, biuret and uretidion. It was reasonable to assign the resonance as urea linkage. The urea linkage formation also supports the long extension chain with a higher first weight loss when MCHP prepared at $60^{\circ} \mathrm{C}$.

If the reaction temperature higher than $60^{\circ} \mathrm{C}$, allophanate, biuret and uretidion may also form other than urea linkage, as called prepolymerization. However, we cannot detect any absorption bands or resonance peaks of urea linkage both in FTIR and NMR. It is because most of HMDI are prepolymerized together and form a gel type in solution so that only a small amount of HMDI grafted on the CHP. That provides another evidence for first weight loss of MCHP prepared in $70^{\circ} \mathrm{C}$ relatively small.

\section{Conclusions}

In the study, we successfully modified the surface of CHP with coupling agent of HMDI). The first weight loss in TGA pattern was increasing with the reaction temperature. When MCHP prepared at the temperature of $60^{\circ} \mathrm{C}(\mathrm{MCHPM})$, the weight loss at $294.6^{\circ} \mathrm{C}$ is about $18.1 \mathrm{wt} \%$ that is much higher than that of any other reaction temperatures. MCHPM will have a long extension chain, which can be formulated as [CHP-O$\left.\mathrm{CO}-\mathrm{NH}-\left(\mathrm{CH}_{2}\right)_{6}-\left(\mathrm{NH}-\mathrm{CO}-\mathrm{NH}-\left(\mathrm{CH}_{2}\right)_{6}\right)_{n}-\mathrm{N}=\mathrm{C}=\mathrm{O}\right]$.

Once the reaction temperature up to $70^{\circ} \mathrm{C}$, HMDI will become various prepolymerized forms with a gel type mixture so that only a small amount of HMDI grafted on the surface of CHP. We suggest that the better temperature for CHP modified by HMDI be around $30-50^{\circ} \mathrm{C}$.

The linkage between HMDI and the surface of CHP is a urethane linkage as $\mathrm{CHP}-\mathrm{O}-\mathrm{CO}-\mathrm{NH}-\left(\mathrm{CH}_{2}\right)_{6}-$ $\mathrm{N}=\mathrm{C}=\mathrm{O}$. After further treatment, the terminal group of MCHP will be converted into a primary amine group as the formula of $\mathrm{CHP}-\mathrm{O}-\mathrm{CO}-\mathrm{NH}-\left(\mathrm{CH}_{2}\right)_{6}-\mathrm{NH}_{2}$. If MCHP prepared at $60^{\circ} \mathrm{C}$, long extension chain will occur with a urea linkage between the isocyanate group as the formula of CHP-O-CO-NH- $-\left(\mathrm{CH}_{2}\right)_{6}-(\mathrm{NH}-\mathrm{CO}-$ $\left.\mathrm{NH}-\left(\mathrm{CH}_{2}\right)_{6}\right)_{n}-\mathrm{NH}_{2}$. If MCHP prepared higher than $60^{\circ} \mathrm{C}$, the HMDI will be prepolymerized together, where allophanate, biuret and uretidion may also form. We cannot detect any absorption bands or resonance peaks of urea linkage both in FTIR and NMR. It is because most of HMDI are prepolymerized together and form a gel type in solution so that only a small amount of HMDI grafted on the CHP.

\section{Acknowledgements}

The author would be grateful to National Health Research Institute of ROC for their kindly financial support on the research.

\section{References}

[1] Gendler E. Perforated demineralized bone matrix: a new form of osteoinductive biomaterial. J Biomed Mater Res 1986;20:687-97.

[2] Lemons JE. Bioceramics: is there a difference? Clin Orthop Relat Res 1990;261:153-8. 
[3] Kitsugi T, Yamamura T, Kokubo T. Bone bonding behavior of $\mathrm{MgO}-\mathrm{CaO}-\mathrm{SiO}_{2}-\mathrm{P}_{2} \mathrm{O}_{5}$ glass. J Biomed Mater Res 1989;23:631-5.

[4] Ogino M, Hench LL. Formation of calcium phosphate films on silicate glasses. J Non-Cryst Solids 1980;38:673-7.

[5] Lin FH, Liao CJ, Liu HC, Chen KS, Sun JS. Behavior of fetal rat osteoblasts cultured in vitro on the DP-bioactive glass substratum. Mater Chem Phys 1997;49:270-6.

[6] Chen TM, Yao CH, Wang HJ, Chou GH, Lee TW, Lin FH. Evaluation of a novel malleable, biodegradable osteoconductive composite in a rabbit cranial defect model. Mater Chem Phys 1998;55:44-50.

[7] Dupraz AMP, de Wijn JR, van der Meer SAT, de Groot K. Characterization of silane-treated hydroxyapatite powders for use as filler in biodegradable composites. J Biomed Mater Res 1996;30:231-8.

[8] Misra DN. Adsorption of zirconyl salts and their acids on hydroxyapatite: use of the salts as coupling agents to dental polymer composites. J Dent Res 1985;12:1405-10.

[9] Liu Q, de Wijn JR, van Blitterswijk CA. Surface modification of hydroxyapatite to introduce interfacial bonding with polyactiveTM 70/30 in a biodegradable composite. J Mater Sci: Mater Med 1996;7:551-7.

[10] Yang JM, Chen HS, Hsu YG, Lin FH. Organic-inorganic hybrid sol-gel materials, 2. Die Angewandte Makromolekulare Chemie 1997;251:61-72.

[11] Liu Q, de Wijn JR, de Groot K, van Blitterswijk CA. Surface modification of nano-apatite by grafting organic polymer. Biomaterials 1998;19:1067-72.

[12] Liu Q, de Wijn JR, van Blitterswijk CA. A study on the grafting reaction of isocyanates with hydroxyapatite particles. J Biomed Mater Res 1998;40:358-64.

[13] Liu Q, de Wijn JR, van Blitterswijk CA. Composite biomaterials with chemical bonding between hydroxyapatite filler particles and PEG/PBT copolymer matrix. J Biomed Mater Res 1998;40:490-7.

[14] Liu Q, de Wijn JR, van Blitterswijk CA. Nano-apatite/polymer composites: mechanical and physicochemical characteristics. Biomaterials 1997;18:1263-70.
[15] Liu Q, de Wijn JR, van Blitterswijk CA. Covalent bonding of PMMA, PBMA, and poly(HEMA) to hydroxyapatite particles. J Biomed Mater Res 1998;40:257-63.

[16] Nakano H, Ohno T, Yamanaka S. Nuclear magnetic resonance spectroscopic study on the grafting ethylene oxide onto the interlayer surface of $\gamma$-zirconium phosphate. Chem Lett 1994; $1: 9-12$.

[17] Karlsson D, Spanne M, Dalene M, Skarping G. Determination of complex mixtures of airborne isocyanates and amines: Part 4. Determination of aliphatic isocyanates as dibutylamine derivatives using liquid chromatography and mass spectrometry. Analyst 1998;123:117-23.

[18] Schwetlick K, Noack R. Kinetic and catalysis of consecutive isocyanate reactions. formation of carbamates, allophanates and isocyanurates. J Chem Soc Perkin Trans 1995; 2:395-402.

[19] Paschalis EP, Tan J, Nancollas GH. Constant composition dissolution kinetics studies of human dentain. J Dent Res 1995 75:1019-26.

[20] Miquel JL, Facchini L, Legrand AP, Rey C, Lemaitre J. Solid state NMR to study calcium phosphate ceramics. Colloids and Surfaces 1990;45:427-33.

[21] Kaji A, Arimatsu Y, Murano M. ${ }^{13} \mathrm{C}-\mathrm{NMR}$ study of anomalous linkages in polyurethane. J Polym Sci: Polym Chem 1992;30: 287-97.

[22] Kakati DK, George MH. Polyurethane ionomers containing phosphate groups. Polymer 1993;34:4319-24.

[23] Desilets S, Villeneuve S, Laviolette M, Auger M. ${ }^{13} \mathrm{C}-\mathrm{NMR}$ spectroscopy study of polyurethane obtained from azide hydroxyl-terminated polymer cured with isophorone diisocyanate (IPDI). J Polym Sci: Polym Chem 1997;35:2991-8.

[24] Jia X, Yu X. Synthesis and properties of polyetherurethane pendant with azo-dye by N-substitution. J Appl Polym Sci 1996; 62:1979-85.

[25] Lin L-K, Lee J-S, Hsu C-K, Huang P-J, Lin H-T. A study on thermal properties of dibasic calcium hydrogen phosphate and monobasic calcium phosphate. Anal Sci 1997;13:413-7. 